\title{
Development of a direct ammonia-fueled molten hydroxide fuel cell
}

\author{
Jun Yang a , Hiroki Muroyama ${ }^{\text {a }}$, Toshiaki Matsui a, and Koichi Eguchi ${ }^{\text {a, }}{ }^{*}$ \\ ${ }^{a}$ Department of Energy and Hydrocarbon Chemistry, Graduate School of Engineering, \\ Kyoto University, Kyoto 615-8510, Japan \\ *Corresponding Author: E-mail: eguchi@scl.kyoto-u.ac.jp, \\ Phone: +81-75-383-2519, FAX: +81-75-383-2520.
}

\begin{abstract}
A fundamental study on direct ammonia fuel cells with a molten hydroxide electrolyte was conducted. The electrochemical oxidation of ammonia on Pt electrode in a molten $\mathrm{NaOH}-\mathrm{KOH}$ electrolyte was investigated by cyclic voltammetry and mass spectrometry. Ammonia was proved to be oxidized to $\mathrm{N}_{2}$ on the Pt electrode during anodic polarization in the molten hydroxide electrolyte. Furthermore, the direct ammonia fuel cell, i.e., $\mathrm{Pt}$ gas diffusion electrode/molten $\mathrm{NaOH}-\mathrm{KOH}$ electrolyte $\mid \mathrm{Pt}$ gas diffusion electrode, was assembled and operated at $200-220{ }^{\circ} \mathrm{C}$. The cell achieved the maximum power density of $c a .16 \mathrm{~mW} \mathrm{~cm}{ }^{-2}$ at $220{ }^{\circ} \mathrm{C}$ with the supply of $\mathrm{NH}_{3}$ and humidified $\mathrm{O}_{2}$ to the anode and cathode, respectively. The mechanism of ammonia oxidation over Pt electrodes in a molten hydroxide electrolyte was discussed based on the results obtained.
\end{abstract}

Keywords: direct ammonia fuel cells; molten hydroxides; ammonia oxidation; platinum electrode; gas diffusion electrode. 


\section{Introduction}

Fuel cells can convert chemical energy to electricity efficiently with low pollutant emissions. Hydrogen is an ideal fuel for this device because of the fast kinetics of electrochemical reaction, high mass energy density, and only water in emission gas. However, the difficulties in storage and transportation of hydrogen hinder its application for commercial fuel cells $[1,2]$. Therefore, various kinds of hydrocarbon fuels, such as methane, methanol, ethanol, and propane, have been investigated intensively as the hydrogen carriers for fuel cells. On the other hand, the demand for a carbon-free fuel source is rising. This is because the by-products originated from the usage of hydrocarbon fuels could severely harm the performance and long-term stability, e.g., $\mathrm{CO}$ for polymer electrolyte fuel cells (PEFCs) and carbon deposited for solid oxide fuel cells (SOFCs) [3-5]. In this respect, recently, ammonia has attracted a considerable interest as a prospective carbon-free fuel source for fuel cells due to the low cost, ease in liquefaction and transportation at ambient temperatures, and high volumetric energy density [6-8].

Several research groups have reported the ammonia-fueled systems, i.e., PEFCs with alkaline anion-exchange membranes (room temperature $100{ }^{\circ} \mathrm{C}$ ), alkaline fuel cells (AFC) with aqueous electrolyte (room temperature $130{ }^{\circ} \mathrm{C}$ ), and SOFCs with oxide ion or proton conductive electrolytes $\left(500 \sim 800{ }^{\circ} \mathrm{C}\right)$ [9-13]. Unfortunately, the first two kinds of systems have the serious problem that the operating temperature is not sufficiently high for the sustainable electrochemical oxidation of ammonia on the anode. As for SOFCs, some promising performance has been obtained with the use of 
ammonia. However, only the hydrogen generated from the thermal decomposition of ammonia serves as the fuel. As a result, the anode material is required to be active for the ammonia decomposition as well as the electro-oxidation of hydrogen.

In addition to the systems introduced above, Ganley has developed a direct ammonia fuel cell composed of lithiated-Ni electrodes and a molten alkaline hydroxides electrolyte. The cell was operated between $200-450{ }^{\circ} \mathrm{C}$, and achieved a maximum power density of $40 \mathrm{~mW} \mathrm{~cm}{ }^{-2}$ at $450{ }^{\circ} \mathrm{C}$ [14]. Although the detailed investigation on the electrochemical ammonia oxidation on the electrode in a molten hydroxide electrolyte has not been conducted, the results indicated the feasibility of direct ammonia fuel cells operated at intermediated temperatures. The molten alkaline hydroxide electrolyte offers extremely high ion-conductivity at intermediate temperatures. For example, Arndt reported that the molten $\mathrm{KOH}$ exhibited an ionic conductivity of $2.5 \mathrm{~S} \mathrm{~cm}^{-1}$ at $400{ }^{\circ} \mathrm{C}$ while that of yttria-stabilized zirconia was approximately $0.1 \mathrm{~S} \mathrm{~cm}^{-1}$ at $1000{ }^{\circ} \mathrm{C}$ [15]. Secondly, the use of molten alkaline hydroxide electrolyte enables to elevate the operating temperature comparing with PEFC and AFC mentioned above. Thus, it is expected that ammonia could be continuously electro-oxidized on the anode.

The overall reaction for the direct ammonia molten hydroxide fuel cell is as follows:

$$
4 \mathrm{NH}_{3}+3 \mathrm{O}_{2} \rightarrow 2 \mathrm{~N}_{2}+6 \mathrm{H}_{2} \mathrm{O}
$$

The electrochemical oxidation of ammonia on the anode in the molten hydroxide is expected to be 


$$
2 \mathrm{NH}_{3}+6 \mathrm{OH}^{-} \rightarrow \mathrm{N}_{2}+6 \mathrm{H}_{2} \mathrm{O}+6 e^{-}
$$

The corresponding cathodic reaction can be expressed as

$$
\mathrm{O}_{2}+2 \mathrm{H}_{2} \mathrm{O}+4 e^{-} \rightarrow 4 \mathrm{OH}^{-}
$$

As a matter of fact, molten alkaline hydroxide eutectics have been employed in direct carbon fuel cells, and the cathode materials for the oxygen reduction reaction (ORR), such as $\mathrm{NiO}$ and FeTi alloys, have been well established [16, 17]. However, the fundamental of ammonia oxidation on the anode has not been elucidated yet.

In this work, therefore, the mechanism for electrochemical oxidation of ammonia over Pt electrode was investigated precisely by cyclic voltammetry and mass spectrometry. Moreover, an ammonia-fueled molten hydroxide fuel cell with Pt gas diffusion electrodes (Pt GDEs) was fabricated, and its performance was evaluated at various temperatures.

\section{Experimental}

A molten hydroxide mixture of $\mathrm{NaOH}-\mathrm{KOH}$ (Wako Pure Chemical Industries) with a weight ratio of $\mathrm{NaOH}: \mathrm{KOH}=43: 57$, which has the lowest melting point (168.8 ${ }^{\circ} \mathrm{C}$ ) in this binary system [18], was kept in a container fabricated by commercial Monel $^{\circledR}$ alloy. The configuration of the cell inside the container is schematically illustrated in Fig. 1a. Each electrode with a Pt lead wire was inserted into the electrolyte through a Teflon tube (inner diameter: $8 \mathrm{~mm}$; outer diameter: $10 \mathrm{~mm}$ ). The electrode area was defined as the area immersed in the liquid electrolyte (illustrated as the oblique-line region in Fig. 1a). As a result, the electrode was isolated from the 
ambient atmosphere by the liquid electrolyte and the Teflon tube. The gas was supplied to the electrode via a thin Teflon tube (inner diameter: $1 \mathrm{~mm}$; outer diameter: $3.2 \mathrm{~mm}$ ). The distance between the two electrodes was $c a .25 \mathrm{~mm}$. A polytetrafluoroethylene (PTFE, Aldrich)-film- sealed Ag wire (diameter: $0.5 \mathrm{~mm}$ ) was immersed into the electrolyte to serve as a reference electrode, which exhibited large exchange current and stable potential in molten $\mathrm{KOH}-\mathrm{NaOH}$ electrolyte [19]. The Teflon tubes, Ag reference electrode, and PTFE film were proved to be stable in the molten hydroxides throughout the tests at the operating temperature range of $200-220^{\circ} \mathrm{C}$.

Pt plate electrode cut from the commercial product $(0.1 \mathrm{~mm}$ in thickness and 0.2 $\mathrm{cm}^{2}$ in electrode area, Nilaco Corp.) was used as a working electrode. The electrochemical measurements for the Pt plate electrode were carried out at $200{ }^{\circ} \mathrm{C}$. Cyclic voltammetry was performed on the Pt plate electrode between -0.9 to $0.3 \mathrm{~V} v s$. Ag reference electrode under a flow of ammonia or argon at a sweep rate of $20 \mathrm{mV} \mathrm{s}^{-1}$. Subsequently, the Pt plate electrode was polarized at -0.25 and $0 \mathrm{~V} v s$. Ag reference electrode with ammonia, and the current density was measured as a function of time. In addition, the product of ammonia oxidation over the Pt plate electrode with an electrode area of $1.0 \mathrm{~cm}^{2}$ was investigated by mass spectrometry. Ammonia was constantly supplied to the Pt plate electrode. After held at OCV for $10 \mathrm{~min}$, the Pt plate electrode was polarized at $-0.25 \mathrm{~V}$ for $30 \mathrm{~min}$, and then held at OCV again. The outlet gas was analyzed by a mass spectrometer (OmniStar GSD 320, Pfeiffer Vacuum AG) throughout the test. 
In order to obtain larger current density than the plate electrode, Pt gas diffusion electrode (Pt GDE, $0.2 \mathrm{~cm}^{2}$ in electrode area) was prepared following the procedure in ref. 20, as is shown in Fig. 1b. Platinum powders (300 mesh, Nilaco Corp.) and PTFE powders $(1 \mu \mathrm{m}$ in diam, Aldrich $)$ with a volume ratio of PTFE:Pt $=3: 2$ were mixed in ethanol by ultrasonic radiation for $15 \mathrm{~min}$. Subsequently, ethanol was vaporized and the resultant powder was pressed into a pellet $(10 \mathrm{~mm}$ in diam.). The as-prepared pellet was hot-pressed into a film ( $c a .0 .1 \mathrm{~mm}$ in thickness) together with a piece of Pt mesh at $300{ }^{\circ} \mathrm{C}$. The Pt GDE was constantly polarized at $-0.25 \mathrm{~V}$. Simultaneously, Ar was flowed to the working electrode for $c a .4$ min at first, and then was switched to ammonia for $2 \mathrm{~min}$. Finally Ar was supplied again. Moreover, the stability of the Pt GDE under polarization was investigated. In these electrochemical measurements, the counter electrode was a Pt plate electrode in $97 \% \mathrm{O}_{2}-3 \% \mathrm{H}_{2} \mathrm{O}$, which was prepared by bubbling oxygen through water. The humidity was controlled to be as low as $3 \%$ so that the concentration of water in the electrolyte would not increase significantly during the experiments. The total gas flow rate for each side was $30 \mathrm{~mL} \mathrm{~min}^{-1}$.

A direct ammonia fuel cell was assembled by employing Pt GDEs. Pure $\mathrm{NH}_{3}$ and $97 \% \mathrm{O}_{2}-3 \% \mathrm{H}_{2} \mathrm{O}$ were supplied to the anode and cathode, respectively. The mixed gas was prepared by bubbling oxygen through water. The current-voltage $(I-V)$ characteristics of the cell as well as the potential of each electrode against $\mathrm{Ag}$ reference electrode were collected at various temperatures. The electrochemical impedance measurement was performed to obtain the ohmic resistance between each electrode and $\mathrm{Ag}$ reference electrode, which was used in the calculation of the 
polarization curves. All the electrochemical measurements were conducted by using a Solartron 1260 frequency response analyzer and a Solatron 1287 electrochemical interface with a signal amplitude of $10 \mathrm{mV}$.

\section{Results and discussion}

Figure 2 shows the cyclic voltammograms of the Pt plate electrode with the supply of $\mathrm{Ar}$ or $\mathrm{NH}_{3}$ at $200{ }^{\circ} \mathrm{C}$. The potential range for cyclic voltammetry in this work was set from -0.9 to $0.3 \mathrm{~V}$ against the $\mathrm{Ag}$ reference electrode considering the following reasons. Miles reported that the reduction of water,

$$
2 \mathrm{H}_{2} \mathrm{O}+2 e^{-} \rightarrow \mathrm{H}_{2}+2 \mathrm{OH}^{-}
$$

determined the cathodic limit as $c a .-1.3 \mathrm{~V} v s$. Ag reference electrode for a system similar as that in this work [19]. Therefore, the lower potential limit has to be fixed higher than this value to avoid the negative influence of coexistent hydrogen. On the other hand, the evolution of $\mathrm{O}_{2}$ in the electrolyte,

$$
4 \mathrm{OH}^{-} \rightarrow 2 \mathrm{H}_{2} \mathrm{O}+\mathrm{O}_{2}+4 e^{-}
$$

started at ca. $0.2 \mathrm{~V} v s$. Ag reference electrode [19]. In order to confirm the accuracy of this measurement, the upper limit was set at around the onset potential of oxygen evolution which will not be affected by the species of supplied gas.

The dashed line in Fig. 2 represents the voltammetric profile of Pt plate electrode with Ar, which is considered as the blank profile for Pt plate electrode in the molten hydroxide electrolyte. At the beginning of the forward scan from $-0.9 \mathrm{~V}$, the reduction current was observed at potentials lower than ca. $-0.55 \mathrm{~V}$. Subsequently, a broad 
oxidation current peak emerged between $c a$. $-0.55 \mathrm{~V}$ and $0.1 \mathrm{~V}$. It is noticed that the peak current density was lower than $0.005 \mathrm{~A} \mathrm{~cm}^{-2}$. An abrupt increase in the oxidation current appeared at above $c a .0 .17 \mathrm{~V}$ due to the evolution of $\mathrm{O}_{2}$ [19]. Two reduction peaks at $c a .0 .04$ and $c a .-0.18 \mathrm{~V}$ were observed in the backward scan. Although further analysis is still required to identify each peak, it is reasonable to assume that the oxidation and reduction peaks between $c a .-0.6$ and $0.15 \mathrm{~V}$ in the profile with $\mathrm{Ar}$ were related with the redox processes of $\mathrm{Pt}$.

The solid line in Fig. 2 shows the cyclic voltammogram of the Pt plate electrode with $\mathrm{NH}_{3}$. The onset potential of oxidation current was $c a$. $-0.67 \mathrm{~V}$ (see the enlarged image in Fig. 2b). Subsequently, the oxidation current increased and achieved the maximum of $c a .0 .02 \mathrm{~A} \mathrm{~cm}^{-2}$ at $c a .-0.2 \mathrm{~V}$. At the potential higher than $c a .0 .15 \mathrm{~V}$, the oxidation current increased rapidly owing to the evolution of oxygen, as is the case for the blank profile with Ar. The close onset potentials of oxygen evolution over the Pt electrode with different supplied gas proved the stability of the potential of the Ag reference electrode. Comparing with the blank voltammogram, ammonia oxidation should be responsible for the anodic current peak between $c a .-0.67 \sim 0.15 \mathrm{~V}$. During the backward scan, the oxidation current was almost zero at the potential range from 0 to $-0.2 \mathrm{~V}$. However, it increased abruptly at $c a .-0.2 \mathrm{~V}$. The decrease in the oxidation current during the forward scan from $c a .-0.2$ to 0.15 should be due to the oxidation of $\mathrm{Pt}$, which significantly reduced the active surface for ammonia oxidation. Moreover, the voltammogram of $\mathrm{Pt}$ plate electrode with $\mathrm{NH}_{3}$ was proved to be reproducible (see Fig. 3). No appreciable change in the profiles of the Pt plate electrode was observed in 
10 cycles.

The Pt plate electrode was subsequently polarized at -0.25 or $-0.05 \mathrm{~V}$ with $\mathrm{NH}_{3}$ for $10 \mathrm{~min}$. The chronoamperometric curves are shown in Fig. 4. At each potential, the anodic current decreased sharply within initial $40 \mathrm{~s}$ due to the growth of the diffusion layer. Afterwards, the current decreased slowly. Even after the potential holding at $-0.05 \mathrm{~V}$ for $10 \mathrm{~min}$, the Pt plate electrode was not significantly deactivated, indicating that ammonia oxidation proceeded continuously on the Pt plate electrode at high potentials.

The Pt plate electrode with larger electrode area $\left(1 \mathrm{~cm}^{2}\right)$ was used for the investigation of product in the outlet gas by mass spectrometry. The electrode was polarized at $-0.25 \mathrm{~V} v s$. Ag reference electrode. The chronoamperometric curve shown in Fig. 5a is similar to that in Fig. 4 except that the duration time was 30 min. The time courses of current passing through the electrode and mass signals for nitrogen $($ mass $/$ charge $=28)$ and hydrogen $($ mass $/$ charge $=2)$ are shown in Fig. 5 b. At the beginning, the electrode was held at OCV. When the anodic potential was added, the signal for nitrogen increased and became stable soon. After the removal of potential, the signal for nitrogen recovered to the background level rapidly. Throughout this experiment, the signal for hydrogen did not change apparently. Therefore, it was qualitatively proved that ammonia oxidation over the Pt plate electrode contributed to the anodic current.

Pt GDEs were used for the molten hydroxide fuel cell. Since the PTFE powder cannot be wetted by the molten $\mathrm{KOH}-\mathrm{NaOH}$, the triple phase boundary of 
$\mathrm{NH}_{3} /$ electrolyte/Pt on the Pt GDE was significantly expanded. As a result, larger current can be achieved on the Pt GDE comparing with the plate electrode. This enables the detection of products via the electrochemical reaction by the mass spectrometry. The Pt GDE was polarized at $-0.25 \mathrm{~V} v s$. Ag reference electrode, and the change in current was recorded with varying the flow gas (see Fig. 6). At the beginning the current density was almost zero with the supply of Ar. Soon after the replacement of supplied gas to $\mathrm{NH}_{3}$, the current increased sharply. Afterwards the gas was replaced with Ar again, and the current dropped immediately to zero.

The Pt GDE exhibited stable performance for the electro-oxidation of ammonia. Figure 7 shows that even after anodically polarized at $-0.25 \mathrm{~V}$ for $60 \mathrm{~min}$ at $200{ }^{\circ} \mathrm{C}$, no significant decrease in the current density was observed. In view of this, a direct ammonia fuel cell composed of the molten $\mathrm{KOH}-\mathrm{NaOH}$ electrolyte and Pt GDEs was fabricated. The $I-V$ characteristics of the cell at different temperatures are shown in Fig. 8. The OCV of the cell was ca. $0.8 \mathrm{~V}$ at $200{ }^{\circ} \mathrm{C}$, which is lower than the theoretical one, $1.15 \mathrm{~V}$. Such a deviation was also reported by Ganley, which might be due to the insufficient electrocatalytic activity of the electrode for ammonia oxidation. The performance of the cell increased with temperature, and the power density reached a maximum of $c a .16 \mathrm{~mW} \mathrm{~cm}^{-2}$ at $220^{\circ} \mathrm{C}$, which was comparable with Ganley's result [14]. The polarization curves for the anode and cathode at $200{ }^{\circ} \mathrm{C}$ were also depicted in Fig. 9. The polarization resistance of the electrodes dominated the cell performance as compared with the ohmic resistance, which disagreed with Ganley's report due to the use of different electrodes [14]. The overpotential of cathode was 
lower than that of anode at low current densities $\left(c a .0 \sim 0.05 \mathrm{~A} \mathrm{~cm}^{-2}\right)$, while this order has changed over $c a .0 .05 \mathrm{~A} \mathrm{~cm}^{-2}$. At this stage, the reason for this behavior is still unknown and further reaction kinetics study is required.

Based on the results displayed above, the mechanism of ammonia oxidation on the Pt electrode at intermediate temperatures is discussed as follows. It is widely accepted that ammonia is oxidized on Pt electrode in aqueous electrolytes at around room temperatures by the stepwise dehydrogenation of $\mathrm{NH}_{3}$ [20-22]. Oswin suggested the steps as follows:

$$
\begin{gathered}
\mathrm{NH}_{3}+\mathrm{OH}^{-} \rightarrow \mathrm{NH}_{2}+e^{-}+\mathrm{H}_{2} \mathrm{O} \\
\mathrm{NH}_{2}+\mathrm{OH}^{-} \rightarrow \mathrm{NH}+e^{-}+\mathrm{H}_{2} \mathrm{O} \\
\mathrm{NH}+\mathrm{OH}^{-} \rightarrow \mathrm{N}_{a d}+e^{-}+\mathrm{H}_{2} \mathrm{O} \\
2 \mathrm{~N}_{a d} \rightarrow \mathrm{N}_{2}
\end{gathered}
$$

where $\mathrm{N}_{\mathrm{ad}}$ denotes the nitrogen atom adsorbed on the electrode. However, referring to the formation of $\mathrm{N}_{2}$ (reaction (9)), Gerischer and Mauerer proposed another mechanism as follows [23]:

$$
\begin{aligned}
\mathrm{NH}_{x}+\mathrm{NH}_{y} \rightarrow \mathrm{N}_{2} \mathrm{H}_{x+y} \quad(x, y=1 \text { or } 2) \\
\mathrm{N}_{2} \mathrm{H}_{x+y}+(x+y) \mathrm{OH}^{-} \rightarrow \mathrm{N}_{2}+(x+y) e^{-}+(x+y) \mathrm{H}_{2} \mathrm{O}
\end{aligned}
$$

In the Gerischer-Mauerer mechanism, $\mathrm{NH}_{x}(x=1$ or 2$)$ species are considered as the active intermediates to form $\mathrm{N}_{2}$ instead of $\mathrm{N}_{\text {ad. }}$ Because $\mathrm{N}_{\mathrm{ad}}$ has a very high adsorption energy on the surface of Pt, it is difficult for two adsorbed nitrogen atoms to form a nitrogen molecule directly. As a result, $\mathrm{N}_{\text {ad }}$ acts as a catalyst poison. This mechanism was supported by a differential electrochemical mass spectrometry study 
performed by Gootzen [24]. The poisoning effect of $\mathrm{Nad}_{\mathrm{ad}}$ on noble metal electrode is fatal for direct ammonia fuel cells at room temperatures. It is frequently reported that noble metals can be deactivated for the electrochemical ammonia oxidation rapidly during anodic polarization in $\mathrm{NH}_{3}$-contained basic solutions [1, 20, 25]. For example, Endo reported that Pt was totally deactivated for ammonia oxidation within $20 \mathrm{~s}$ at $-0.5 \mathrm{~V}$ vs. RHE in $0.1 \mathrm{M} \mathrm{NH}_{3}-1 \mathrm{M} \mathrm{KOH}$ aqueous solution [1]. However, as is demonstrated in Fig. 4, the performance of the Pt electrode remained for a much longer period at the high potential. This result suggests that $\mathrm{N}_{\mathrm{ad}}$ no longer acts as the catalyst poison at elevated temperatures. Instead, it serves as an intermediate species. As a result, in addition to reaction (11), $\mathrm{N}_{2}$ can also be formed by the combination of two $\mathrm{N}_{\mathrm{ad}}$ as described by reaction (9), and thus allows the sustainable ammonia oxidation on the anode for direct ammonia fuel cells.

\section{Conclusions}

The electrochemical oxidation of ammonia on Pt electrodes was investigated by cyclic voltammetry and mass spectrometry. The Pt electrode was demonstrated to be active for the electrochemical ammonia oxidation in the molten hydroxide electrolyte. A direct ammonia fuel cell using Pt GDEs and eutectic $\mathrm{NaOH}-\mathrm{KOH}$ electrolyte was successfully operated at $200-220^{\circ} \mathrm{C}$. The polarization resistance dominated the performance of the cell. Although the performance of the cell was not satisfying comparing with other mature fuel cells, the feasibility of direct ammonia fuel cell systems was confirmed. Better performance can be achieved by developing more 
active materials and optimizing the design of the cell. Furthermore, it is expected that by replacing the PTFE materials with ceramics, which should be stable and unwettable in molten hydroxides, the operating temperature could be further elevated and the performance of the fuel cell will be significantly improved.

\section{Acknowledgement}

This work was supported by the Advanced Low Carbon Technology Research and Development Program (ALCA) of the Japan Science and Technology Agency (JST). 


\section{References}

1. K. Endo, Y. Katayama, T. Miura, Electrochimi. Acta 49 (2004) 1635-1638.

2. F. J. Vidal-Iglesias, J. Solla-Gullon, V. Montiel, J. M. Feliu, A. Aldaz, J. Power Sources 171 (2007) 448-456.

3. P. Waszczuk, A. Wieckowski, P. Zelenay, S. Gottesfeld, C. Coutanceau, J.-M Leger,

C. Lamy, J. Electroanal. Chem. 511 (2001) 55-64.

4. F. A. Uribe, S. Gottesfeld, T. A. Zawodzinski, J. Electrochem. Soc. 149 (2002) A293-A296.

5. R. Halseid, P. J. S. Vie, R. Tunold, J. Power Sources 154 (2006) 343-350.

6. K. Kordesch, V. Hacker, J. Gsellmann, M. Cifrain, G. Faleschini, P. Enzinger, R. Fankhauser, M. Ortner, M. Muhr, R.R. Aronson, J. Power Sources 86 (2000) 162-165. 7. B. H. Liu, Z. P. Li, J. Power Sources 187 (2009) 291-297.

8. K. Kordesch, V. Hacker, J. Gsellmann, M. Cifrain, G. Faleschini, P. Enzinger, R. Fankhauser, M. Ortner, M. Muhr, R. R. Aronson, J. Power Sources 86 (2000) $162-165$.

9. E. L. Simons, E.J. Cairns, D.J. Surd. J. Electrochem. Soc. 116 (1969) 556-561.

10. J. R. Varcoe, R. C. T. Slade, Fuel Cells 5 (2005) 187-200.

11. A. Wojcik, H. Middleton, I. Damopoulos, J. Van herle, J. Power Sources 118 (2003) 343-348.

12. N. Dekker, G. Tietveld, J. Fuel Cell Sci. Technol. 3 (2006) 449-502.

13. S. Suzuki, H. Muroyama, T. Matsui, K. Eguchi, J. Power Sources 208 (2012) 257-262. 
14. J. C. Ganley, J. Power Sources 178 (2008) 44-47.

15. K. Arndt, G. Ploetz, Z. Phys. Chem. 121 (1926) 439-455.

16. S. Zecevic, E. M. Patton, P. Parhami, Chem. Eng. Comm. 192 (2005) 1655-1670.

17. S. Zecevic, E. M. Patton, P. Parhami, Carbon 42 (2004) 1983-1993.

18. H. Otto, R. P. seward, J. Chem. Eng. data (1964) 507-508.

19. M. H. Miles, J. Appl. Electrochem. 33 (2003) 1011-1016.

20. Y. Shimizu, K. Uemura, H. Matsuda, N. Miura, N. Yamazoe, J. Electrochem. Soc. 137 (1990) 3430-3433.

21. H. G. Oswin, M. Salomon, Canad. J. Chem. 41 (1963) 1686-1694.

22. A. R. Despic, D. M. Drazic, P. M. Rakin, Electrochim. Acta 11 (1966) 997-1005.

23. H. Gerischer, A. Maurerer, J. Electroanal. Chem. 25 (1970) 421-433.

24. J. F. E. Gootzen, A. H. Wonders, W. Visscher, R. A. van Santen, J. A. R. van Veen, Electrochim. Acta 43 (1998) 1851-1861.

25. V. Rosca, M. T. M. Koperw, Phys. Chem. Chem. Phys. 8 (2006) 2513-2524 


\section{Figures}

Fig. 1. Schematic illustration of (a) the molten hydroxide fuel cell and (b) the gas diffusion electrode.

Fig. 2. (a) Cyclic voltammograms of Pt plate electrode with $\mathrm{Ar}$ or $\mathrm{NH}_{3}$ at $200{ }^{\circ} \mathrm{C}$ (sweep rate: $20 \mathrm{mV} \mathrm{s}^{-1}$ ); (b) an enlarged image of the profiles between -0.75 and $-0.35 \mathrm{~V}$ in (a).

Fig. 3. Cyclic voltammogram (10 full cycles) of Pt plate electrode with $\mathrm{NH}_{3}$ at $200{ }^{\circ} \mathrm{C}$ (sweep rate: $20 \mathrm{mV} \mathrm{s}^{-1}$ ).

Fig.4. Chronoamperometric curves of $\mathrm{Pt}$ plate electrode with $\mathrm{NH}_{3}$ anodically polarized at -0.25 or $-0.05 \mathrm{~V}$ at $200^{\circ} \mathrm{C}$.

Fig. 5. Time courses of (a) the current passing the Pt plate electrode (electrode area: 1 $\mathrm{cm}^{2}$ ) polarized at $-0.25 \mathrm{~V} v s$. Ag reference electrode and (b) the corresponding mass signals of hydrogen and nitrogen (mass/charge $=2$ and 28) in the exhausted gas of the Pt plate electrode.

Fig. 6. Chronoamperometric curve of Pt GDE under anodic polarization at $-0.25 \mathrm{~V} v s$. Ag reference electrode at $200{ }^{\circ} \mathrm{C}$; Ar was flowed for $c a .270 \mathrm{~s}$, followed by the 
ammonia supply for $2 \mathrm{~min}$ and then Ar was supplied again.

Fig. 7. Time course of current density for the Pt GDE under anodic polarization at $-0.25 \mathrm{~V}$ vs. Ag reference electrode with $\mathrm{NH}_{3}$ at $200{ }^{\circ} \mathrm{C}$.

Fig. 8. Cell voltage (hollow) and power density (solid) as a function of current density for the cell of $\mathrm{NH}_{3}$, Pt GDE | KOH-NaOH $\mid \mathrm{Pt}$ GDE, $\mathrm{O}_{2}-\mathrm{H}_{2} \mathrm{O}$ at various temperatures.

Fig. 9. Overpotential of the $\mathrm{Pt}$ gas diffusion anode (with $\mathrm{NH}_{3}$ ) and cathode (with $\left.\mathrm{O}_{2}-\mathrm{H}_{2} \mathrm{O}\right)$ as a function of current density at $200{ }^{\circ} \mathrm{C}$. 

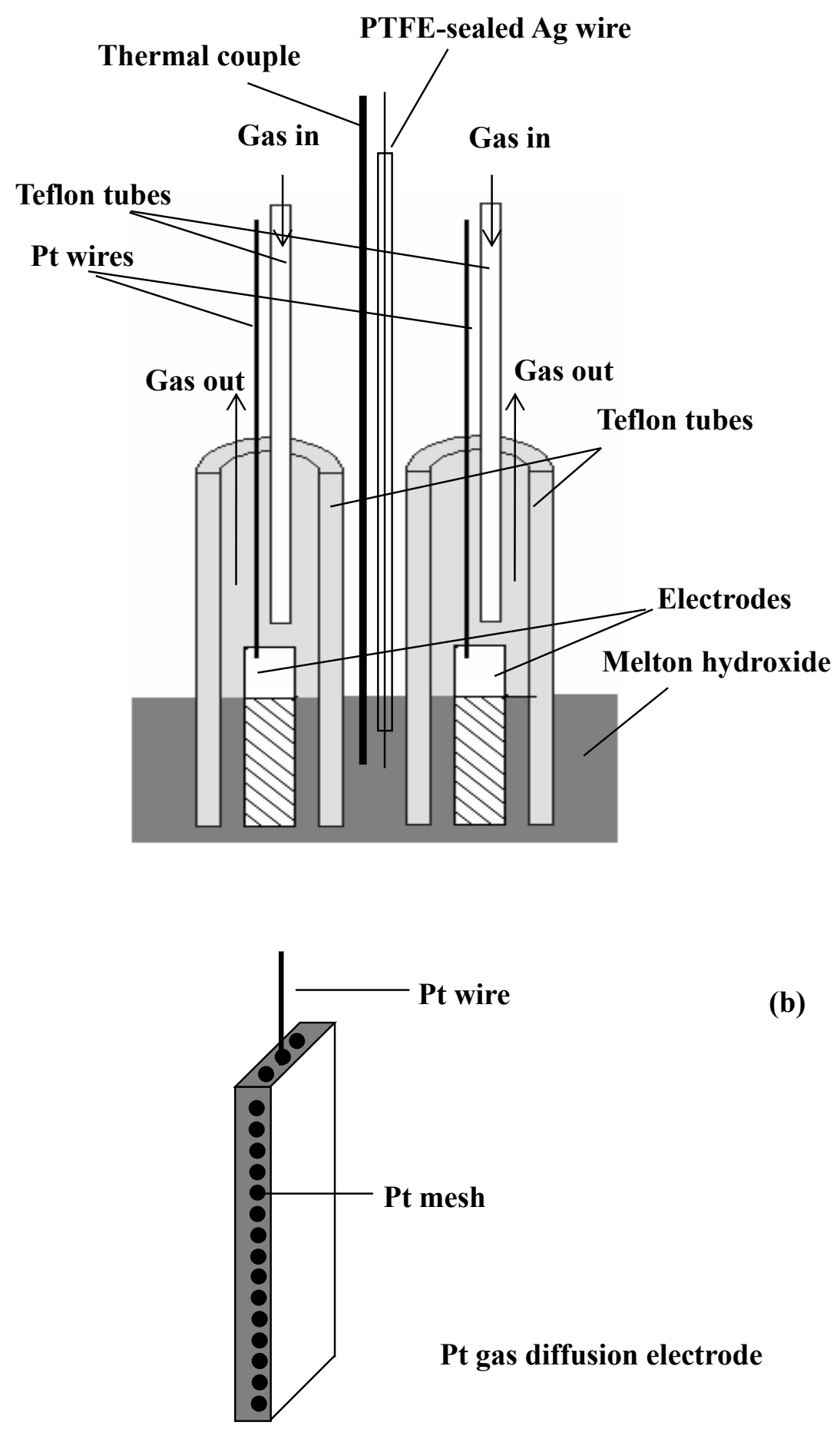

(b)

Figure 1. J. Yang et al. 

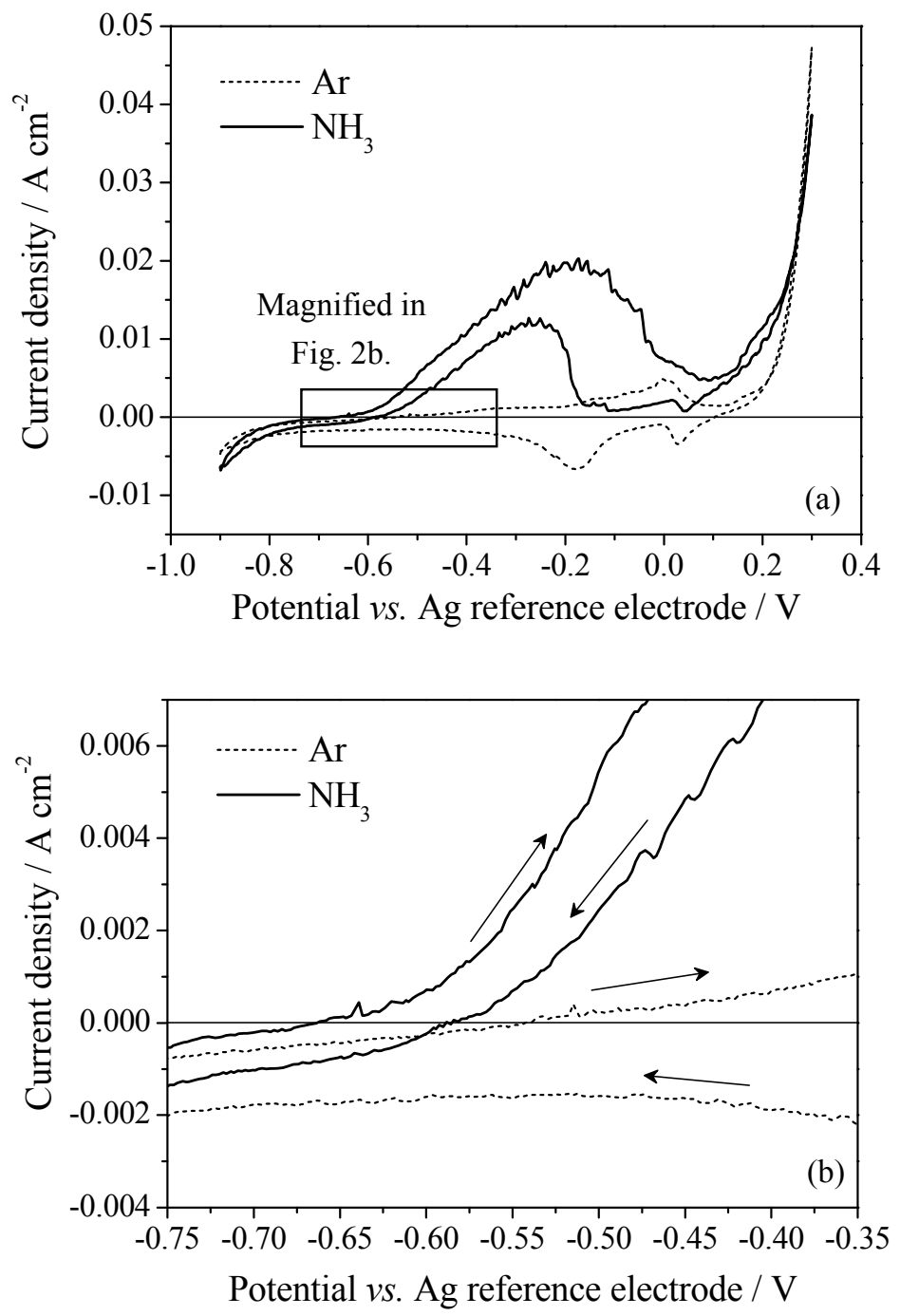

Figure 2. J. Yang et al. 


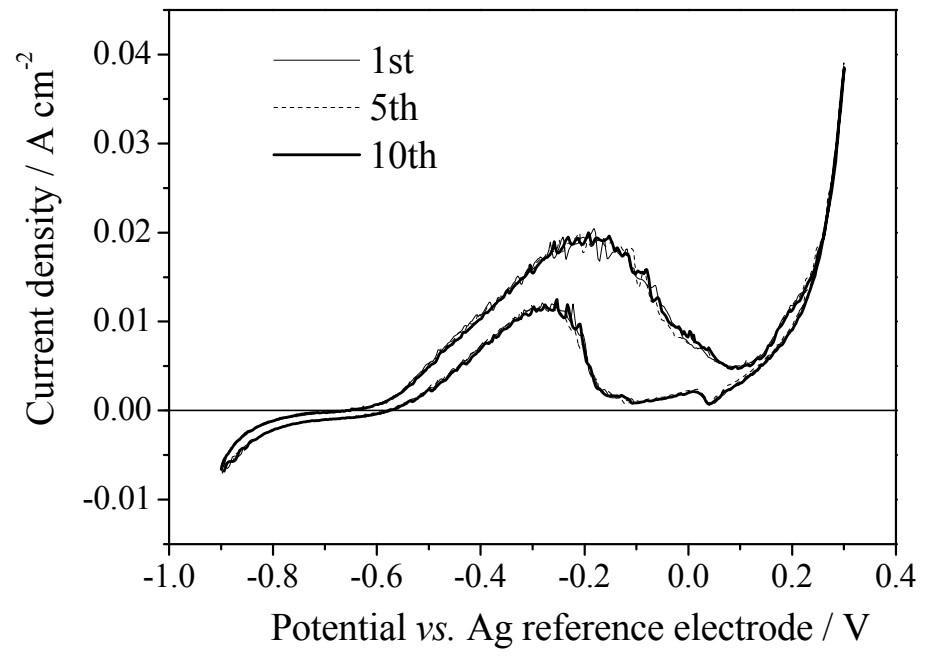

Figure 3. J. Yang et al. 


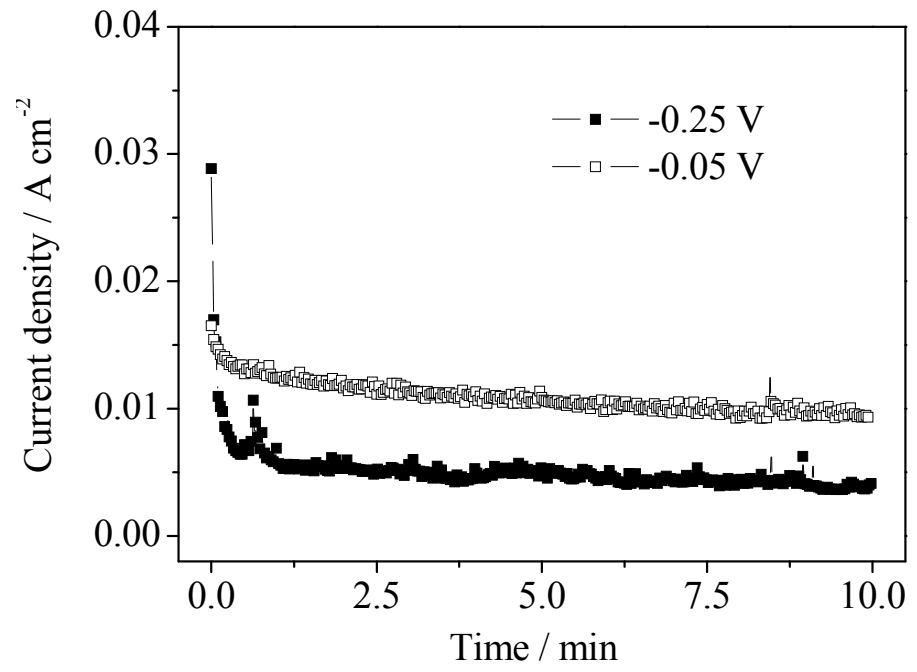

Figure 4. J. Yang et al. 

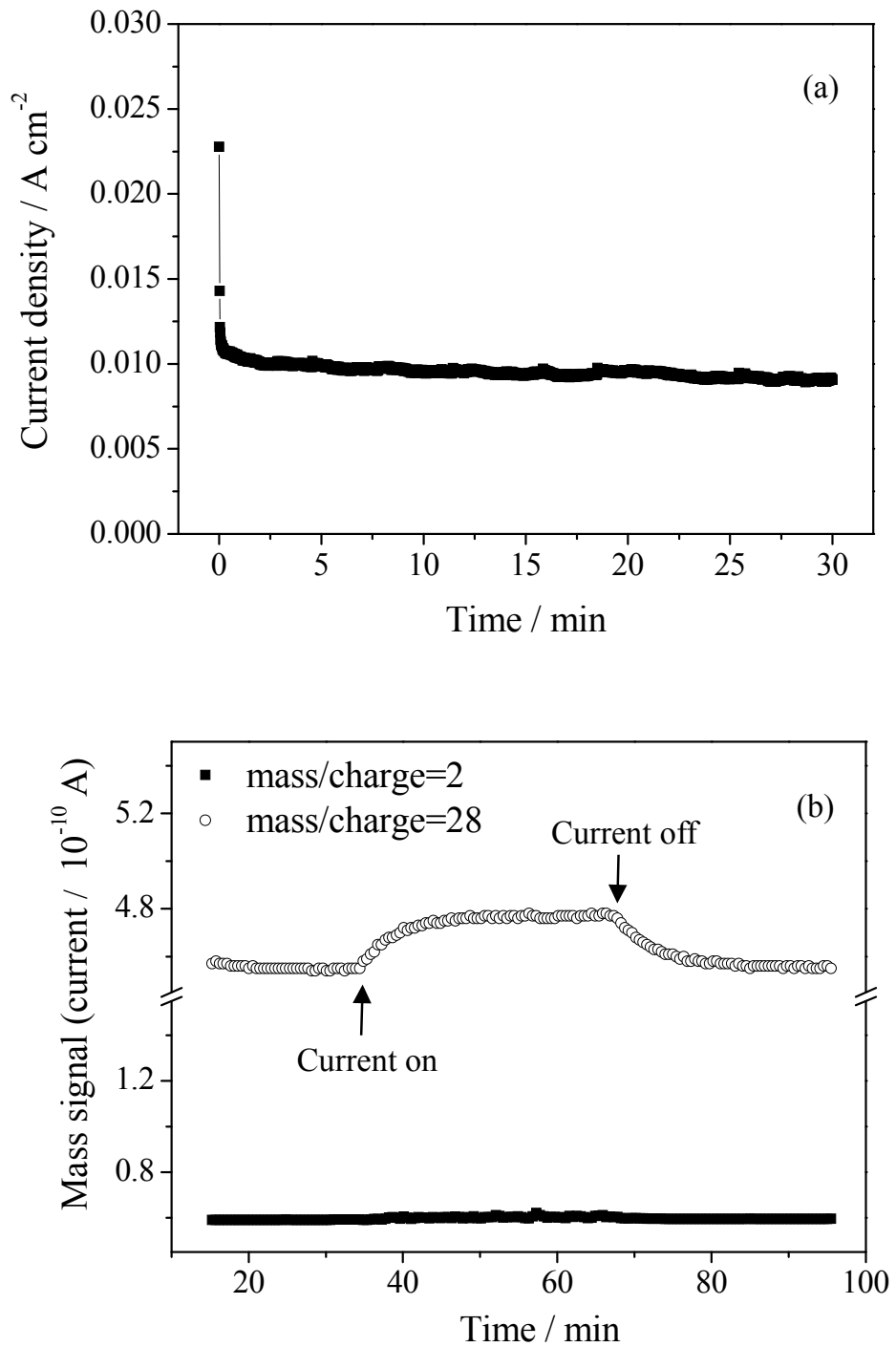

Figure 5. J. Yang et al. 


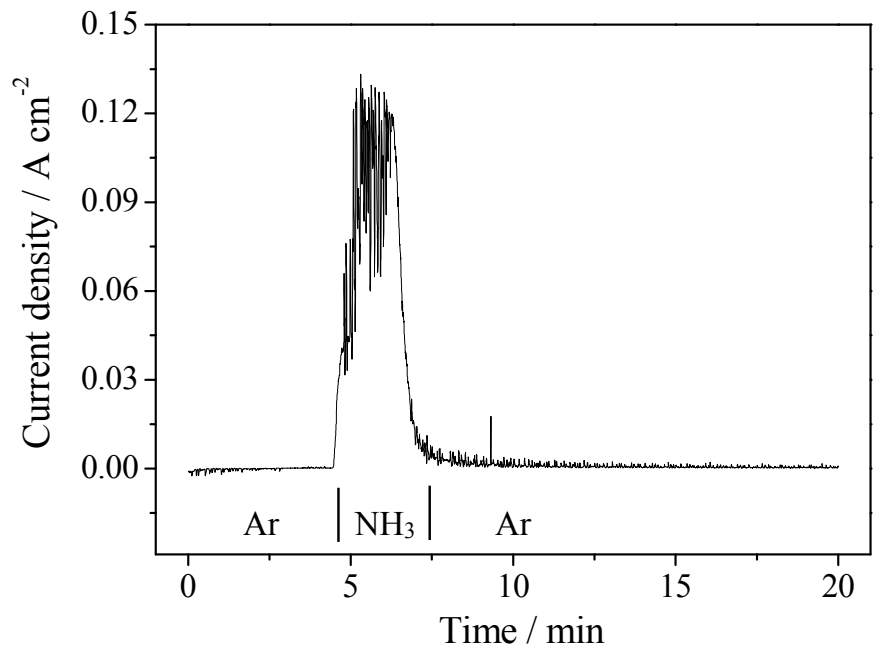

Figure 6. J. Yang et al. 


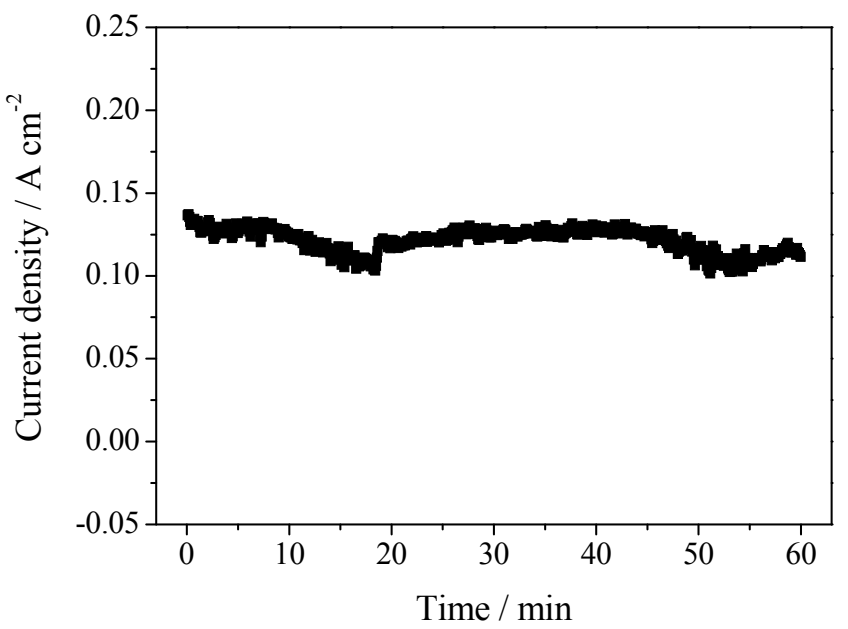

Figure 7. J. Yang et al. 


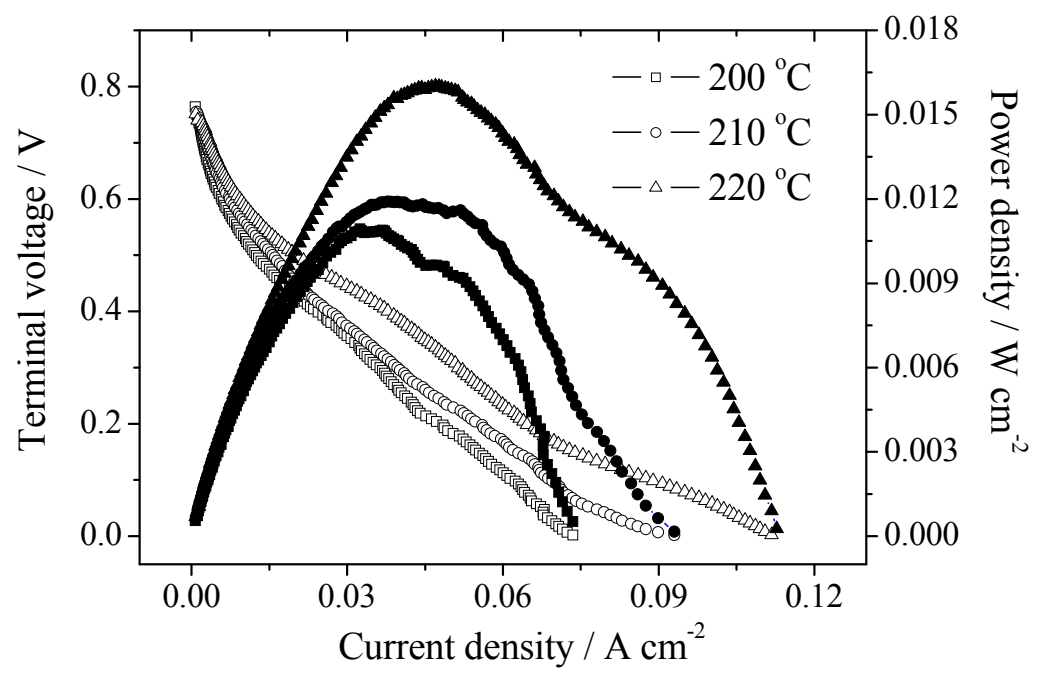

Figure 8. J. Yang et al. 


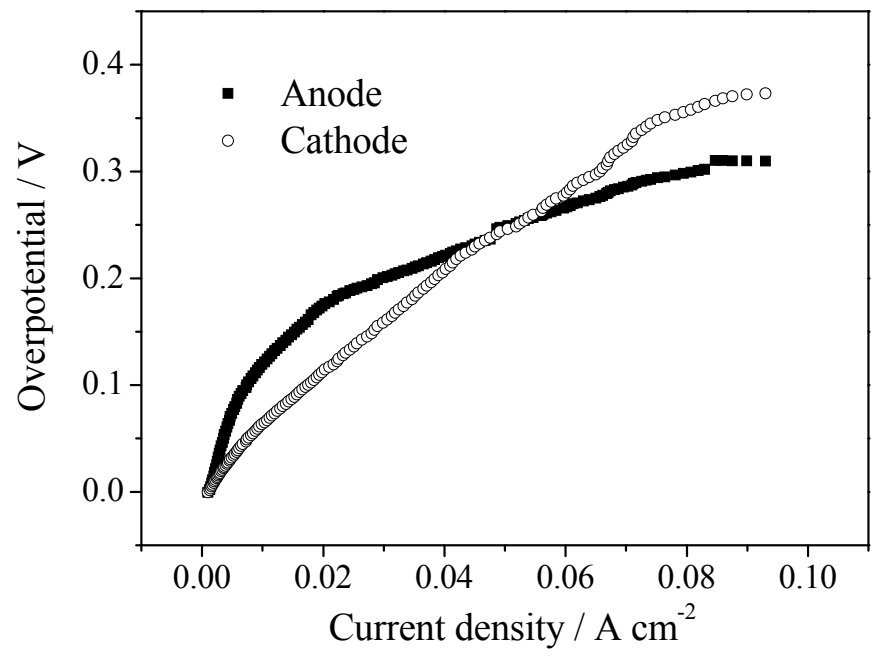

Figure 9. J. Yang et al 